\title{
REMOTE LEARNING UNDER THE COVID-19 SOCIAL DISTANCING: REFLECTIONS AND A NETNOGRAPHY STUDY
}

Vitor Hideo Nasu http://orcid.org/0000-0002-5176-6634

Universidade de São Paulo, São Paulo, SP, Brazil

\begin{abstract}
The purpose of this work is two-fold. First, it intends to discuss and reflect on the transition from faceto-face to remote learning in accounting education because of the COVID-19 pandemic. And second, it presents the results of a netnography study conducted at the beginning of the COVID-19 outbreak in Brazil (March and April of 2020). I also provide some personal experiences during these times. In section 2, I provide key technology resources I found helpful for accounting instructors and students. In section 3, I discuss the implications for instructors and students brought by the COVID-19. I especially appreciate the effors that both instructors and students are doing to keep their academic lives going, despite all the adversity. In section 4, I describe a netnography study in which I examined data from a graduate students' Facebook community. And in section 5, I report closing thoughts.
\end{abstract}

Keywords: COVID-19, Remote learning, Social distancing; Netnography; Accounting.

\section{INTRODUCTION}

The purpose of this work is two-fold. First, it intends to discuss and reflect on the transition from the face-to-face to remote learning in accounting education because of the COVID-19 pandemic. And second, it presents the results of a netnography study conducted at the beginning of the COVID-19 outbreak in Brazil (March and April of 2020). The novel coronavirus causes COVID-19, a pathology in which symptoms are similar to the regular flu, but can cause, in addition, chronic respiratory conditions that may lead people to death, especially those who are 60 years old or more and with pre-existing diseases. COVID-19 has a high level of transmission among humans and extreme measures are needed to constrain its spreading. The World Health Organization (WHO) considered it a pandemic on March 11, 2020. In Brazil, the first case of COVID-19 was detected at the end of February 2020 and since then it has spread to many Brazilian states and cities, making more than two hundred thousands of victims (as of January 25, 2021).

Manuscript first received: 2021-01-28. Manuscript accepted: 2021-03-16.

Address for correspondence: Vitor Hideo Nasu, University of Sao Paulo (USP), Brazil

Email:vnasu@usp.br 
COVID-19 has brought many significant changes to people's lives. More than never, individuals need to use masks, wash their hands frequently, use hand sanitizer, stay at and work from home, be socially distant, and keep informed about other preventing forms and treatments. It also has brought fundamental changes in the way we work, interact, and transmit knowledge. Focusing on this last point, schools have suspended their academic calendar and closed their doors. Other schools have transitioned their face-to-face classes to the virtual environment. And this change has considerable implications for instructors and students. In accounting education, there are barriers to adopt technology (Watty, McKay, \& Ngo, 2016), but given that remote learning is a reality for most of accounting educators while COVID-19 pandemic lasts, they cannot ignore it.

Likewise, students had also to adopt technology. However, as they grew up with it, it may be easier for them, and some might even like its incorporation to the learning process. Rizun and Strzelecki (2020) examined factors that influenced students' acceptance to use technology when shifting from conventional education to remote learning. They collected data from 1692 Polish undergraduate and graduate students and found that enjoyment and self-efficacy are key variables that positively relate to students' acceptance. Perceived ease of use and perceived usefulness had also been found to predict it. These results support technology must be easy to use and helpful to learn.

The transition from face-to-face classes to remote education has been having significant implications for accounting faculty and students, as introduced previously. And this is the first point I intend to discuss and hopefully be insightful. In the next sections, I will also be suggesting materials and other online resources that can assist accounting instructors and students to deal with their tasks better. The second aim of this study is to present the results of a netnography investigation I conducted at the beginning of the COVID-19 outbreak in Brazil. This second point has a larger scope and might be of interest of people who are involved with graduate students and online communities.

This work contributes to prior literature by bringing higher awareness to accounting professors and students regarding online educational tools and resources that can be employed to study and teaching accounting. They can keep being used after the COVID-19 pandemic as well. Besides, I discuss some implications for faculty and students I found essential during this period. And finally, I present the results of a netnography study and report my impressions to complement them. I strongly believe that people can learn from other people's experiences and some might identify themselves with these results and my accounts.

\section{REMOTE LEARNING AND RESOURCES}

The COVID-19 pandemic basically "gave" two options for higher education institutions (HEIs) that offer in-person undergraduate accounting programs. One, onsite classes were suspended and would return after a more controlled scenario of the pandemic. Or two, onsite classes were transitioned to the virtual environment through the use of technology. After almost a year after the start of the pandemic, most of HEIs have transitioned to remote classes and this was where the first issue emerged.

Some accounting instructors and students were not prepared to teach and learn online because of the lack of preparation. Without proper training, they had to suddenly move from face-to-face to remote learning. Many decisions had to be made, such as which online platform to use, whether they had proper remote devices and internet connection, and whether they had access to materials they 
needed (both digital and physical). Fortunately, the accounting profession has become more digital than ever and a great part of the job is done online. This must have facilitated learning in some ways.

Nonetheless, from where I am viewing the implications of COVID-19, the adoption of remote learning is the primary one for instructors and students. And they had to do so in such an emergency fashion with no or little knowledge on how to deal with modern educational technologies. For this reason, I do admire (more) professors and students who decided to transfer their onsite classes to the remote ones and have been employing significant efforts to make it happen without a significant loss of quality in the process. Section 2 is about them. I present some more resources that accounting educators can use in their remote classes or learn how to use new tools to teach, interact, or assess their students. As we approach one year after the beginning of the pandemic, students and faculty are more skilled and prepared in terms of technology management. However, these resources can still improve their classes by diversifying how they teach and learn and promoting a more dynamic online environment.

Students are accustomed to lecturing-based onsite classes where they act passively most of the time. The COVID-19 pandemic has taken away from some accounting instructors their comfort zone by making them use technology. However, transitioning to the virtual environment enables the instructor to use multiple tools to interact with students and register their participation. If video conferencing-based classes are adopted, for instance, students must be alert as technology tools can measure accurately how much time they stayed in the class or took to complete activities. There is a higher level of monitoring. Researchers have also called for attention to student cheating in remote learning (Reyneke, Shuttleworth, \& Visagie, 2021). For example, accounting instructors can and must use short questions interspersed with their lectures to observe whether there are some students who are not paying attention to the class.

There is no doubt that the COVID-19 has brought multiple challenges to accounting education. Nonetheless, there was also space for opportunity (Sangster, Stoner, \& Flood, 2020). According to perceptions of accounting instructors, this was the time to realign teaching and learning strategies besides the traditional education format (Sangster et al., 2020). In Brazil, Professors Claudio A. Wanderley and Kate E. Horton (as cited in Sangster et al., 2020) have suggested that the adoption of the remote education model has saved time due to lengthy commutes between the university and work/home. This model also reflects the digitalization of the accounting profession (Sangster et al., 2020).

\subsection{Digital video and webinars}

In times of COVID-19, digital videos are one of the online approaches that accounting educators have to deliver content and prior research can be of assistance to implement them (D'Aquila, Wang, \& Mattia, 2019; Holtzblatt \& Tschakert, 2011). For example, D’Aquila et al. (2019) developed Youtube videos about accounting topics for students to learn and practice exercises for exams. They also found evidence that the videos created enhanced student performance, as well as students thought that they should be used in class, although it does not necessarily mean that traditional classes should be replaced by the videos.

Videoconferencing has become an essential technology resource that can be employed to communicate with students orally and visually in both synchronous and asynchronous activities. Holtzblatt and Tschakert (2011) point out that, in the past, accounting students were physically attending 
accounting courses, but with the advent of internet and videoconference, a notable advantage is that they can be anywhere while the instructor explains accounting topics. There is no physical barrier when it comes to online classes other than the access to internet. But nowadays even the internet is more popularized and mobile devices as well.

The camera of mobile phones is being used to record any sort of videos, from funny to academic ones. Accounting instructors and students can take advantage of them too. A lot of accounting content videos exist on YouTube ${ }^{\circledR}$, for example. Zoom $\AA$, Skype ${ }^{\circledR}$, Google Hangouts ${ }^{\circledR}$, and other videorecording tools must be used to keep accounting education going in these COVID-19 times. Results from prior literature show that online classes do not necessarily have a negative impact on student performance. There is recent evidence that digital videos have increased it (D'Aquila et al., 2019) and online classes are as good as in-person ones (Fortin, Viger, Deslandes, Callimaci, \& Desforges, 2019). This evidence has made me reflect that online courses can maintain in-person class quality.

Accounting academic bodies, such as the American Accounting Association (AAA) and the European Accounting Association (EAA), have taken the lead to provide their associates with high-quality education tools and materials. For example, on the AAA's website (https://aaahq.org/), accounting instructors can watch webinars on how to make the transition from onsite classes to online ones. In particular, I recommend the following two: (i) "Transition to Remote Learning," hosted by Jill Mitchell and DeAnna Martin (https://aaahq.org/Education/Resources/Online/Transition-to-RemoteLearning); and (ii) Tips and Tools for Organizing Your Online Course in a Hurry," hosted by Wendy Tietz, Jennifer Cainas, and Tracie Miller-Nobles (https://aaahq.org/Education/Resources/Online/Tipsand-Tools-for-Organizing-Your-Online-Course-in-a-Hurry). There are also explaining videos about education tools that can be useful for instructors.

Likewise, the EAA has recently founded the Accounting Resources Centre (https://arc.eaa-online. org/) where a variety of topics within the scope of accounting are discussed and materials provided. Associates can access its blog, publications, job opportunities, repository, and more. For example, Discord, a voice and chat application, allows instructors to create collaborative classes (https://arc.eaa-online.org/ blog/creating-collaborative-virtual-classroom-case-discord). Although it might not meet the needs some accounting instructors, others may want to check this out. Another institution that have been providing teaching materials and webinars for online classes is the Harvard Business Publishing - Education (https://hbsp.harvard.edu/teaching-online-resources/).

In these emergency times to go online, accounting faculty can make the most of webinars and other resources to better prepare themselves and their classes. Especially for those who have little or no experience with technology tools, this is a great opportunity to get out of their comfort zone and get skilled at something different that can help them even after the COVID-19 crisis. Webinars and YouTube videos are useful resources to get information and learn how to teach at distance. It is not easy, but accounting instructors have done so much so far that I believe they can do more if they want.

Watty et al. (2016) indicated that the time to learn and the modification of the class design have been seen as two of the main barriers to avoid the usage of technology by accounting academics. Learning how to utilize new tools does demand a significant amount of time and class redesigning. But in a pandemic scenario where social distancing is necessary, there are little options to keep accounting education going without using technology. From a positive perspective though, once accounting instructors are able to manage these new tools, they will be better prepared to address their students' needs during and after this crisis. 


\subsection{Technology tools for teaching and learning}

Prior to COVID-19, technology use was optional (Fogarty, 2020). but then it became a pandemic and has accelerated the pace instructors embrace technology (Reyneke et al., 2021). Currently, technology is not only a trend, but a necessity and each tool can assist the learning process in particular ways. In the next lines, I will discuss some tools and processes I find important. I will also suggest some others for further consideration by accounting educators. There is no perfect tool that will meet all the needs of instructors and students, but a mix of a few may already make a big difference to teaching and learning.

The first tool we need to acknowledge as important to remote education is the virtual learning environment (VLE), or learning management system (LMS). It enables instructors to upload and download files, organize their classes, engage students in forum discussions, send e-mails to students, create synchronous and asynchronous activities, structure online homework and exams, and so forth. VLEs are pretty useful and may serve as the basis of an online education process. Table 1 shows some examples.

The real-time communication tool, or video conference technology (VCT), is another key resource. It allows instructors and students to communicate instantly and is often utilized to deliver and/or record classes, which can be made available on the VLE. According to prior research (Charron \& Raschke, 2014), accounting information system students reported higher levels of satisfaction when using Skype and Jing (now TechSmith Capture), two types of VCTs. It was also concluded that the virtual instructor support was as effective as the in-person one. While social distancing is active, VCTs are even more crucial to make the learning process happen. Table 2 reports some examples that accounting instructors are already using or may want to take a look at.

The next tool is called student response system (SRS). This tech resource enables interactive activities, such as online quizzes. Instructors can use it for both summative and formative assessment. It also promotes student engagement and satisfaction (Kokina \& Juras, 2017; Paz, 2017). However, its effects on learning are still inconclusive. While some studies found a positive association (Premuroso, Tong, \& Beed, 2011), others found no association at all (Paz, 2017). Prior research provides tips to maximize its use in accounting education (Kokina \& Juras, 2017), and I think they are pretty helpful, especially for those who are considering using SRS. Table 3 shows some options of SRS technology.

Another resource is digital storytelling (DS). It is "a multimodal instructional design framework that helps to explain complex concepts using narrative and metaphor" (Taylor, Marrone, Tayar, \& Mueller, 2017, p. 1). DS involves many modes of representations, such as linguistic, gestural, visual, auditory, and spatial (Istenic Starčič, Cotic, Solomonides, \& Volk, 2016). There is evidence that DS improves student motivation, memory, and make connections between theory and real-world aspects (Taylor et al., 2017). Faculty can record videos to tell stories and narratives in ways that students get engaged and learn how those are connected with accounting concepts and practice. Table 4 reports some options for developing online stories.

Online games (Calabor, Mora, \& Moya, 2019; Carenys \& Moya, 2016) and gamification (Bell, 2018; Buckley \& Doyle, 2016) are also relevant alternative teaching strategies in remote learning. According to a Delphi study (Buckley \& Doyle, 2016), there is little research on these topics in accounting education and there is a low level of usage of learning-based games. Although one could consider these to be negative points, I also want to highlight that at the same time there is room for improvement. Online games and gamification of the educational process are the reality of our current 
Table 1 - Virtual learning environment tools

\begin{tabular}{|c|c|}
\hline VLE & Website \\
\hline Moodle & https://moodle.org/ \\
\hline IntelliBoard & https://intelliboard.net/ \\
\hline Blackboard & https://www.blackboard.com/ \\
\hline Chamilo & https://chamilo.org/en/ \\
\hline Docebo & https://www.docebo.com/ \\
\hline Canvas & https://www.instructure.com/canvas/ \\
\hline
\end{tabular}

Note: Websites were last accessed on January 26, 2021.

Table 2 - Real-time communication tool

\begin{tabular}{|c|c|}
\hline VCT & Website \\
\hline TechSmith Capture (formerly Jing) & https://www.techsmith.com/jing-tool.html \\
\hline Skype & https://www.skype.com/en/ \\
\hline Google Meet & https://meet.google.com/ \\
\hline Zoom & https://zoom.us/ \\
\hline GoToMeeting & https://www.gotomeeting.com/ \\
\hline RingCentral Video & https://www.ringcentral.com/ \\
\hline Microsoft Teams & https://www.microsoft.com/en-us/microsoft-teams/group-chat-software/ \\
\hline U Meeting & https://u.cyberlink.com/ \\
\hline ClickMeeting & https://clickmeeting.com/ \\
\hline BigBlueButton & https://bigbluebutton.org/ \\
\hline
\end{tabular}

Note: Websites were last accessed on January 26, 2021.

Table 3 - Student response system

\begin{tabular}{|c|c|}
\hline SRS & Website \\
\hline iClicker & https://www.iclicker.com/ \\
\hline Kahoot & https://kahoot.com/ \\
\hline Socrative & https://www.socrative.com/ \\
\hline Mentimeter & https://www.mentimeter.com/ \\
\hline Verso & http://versoapp.com/ \\
\hline Nearpod & https://nearpod.com/ \\
\hline Poll Everywhere & https://www.polleverywhere.com/ \\
\hline TopHat & https://tophat.com/ \\
\hline
\end{tabular}

Note: Websites were last accessed on January 26, 2021.

Table 4 - Digital storytelling

\begin{tabular}{|c|c|}
\hline DS & Website \\
\hline Storyline Online & https://www.storylineonline.net/ \\
\hline Storytel & https://www.storytel.com/br/pt/ \\
\hline Bubblr & https://www.pimpampum.net/en/project/bubblr-2/ \\
\hline MakeBeliefsComix & https://www.makebeliefscomix.com/ \\
\hline SmileBox & https://www.smilebox.com/ \\
\hline Storybird & https://storybird.com/ \\
\hline
\end{tabular}

Note: Websites were last accessed on January 26, 2021. 
and future university students. When people must stay at home, online games can be entertaining. And accounting instructors should analyze their students' behavior to decide whether they can take advantage of it for education purposes. In Table 5, I make accounting gaming suggestions.

Finally, I emphasize the importance of business simulations and cases (Hoelscher \& Mortimer, 2018; Riley, Cadotte, Bonney, \& MacGuire, 2013). Most of them can be used in online education. Instructors should then be able to extract their benefits to provide effective learning of accounting concepts and technical skills. Business simulations fit remote classes because they are played in the virtual environment already. Business cases are used in distinct ways. Each case might demand a different approach. One manner to do that is to provide the case in advance and then discuss it during the remote class. Students are submitted to a series of questions related to the case after the discussion. Accounting instructors must select the best approach possible to use it. In addition, business cases are useful to teach how to manage software packages. For instance, Hoelscher and Mortimer (2018) designed a case to be utilized with the Tableau software (https://www.tableau. com/). Besides accounting, students learn a relevant tech skill. Table 6 shows accounting cases that instructors may be interested in.

Other teaching strategies do exist and can also help accounting instructors and students. In this section, I highlighted some of the most essential ones that I believe are effective for remote classes. Accounting educators need to take into account what strategy best suits their classes and educational goals. Because remote learning is something that hopefully will end shortly, user-friendly resources may be prioritized because both educators and students have already a lot to be concerned about during COVID-19 times.

Table 5 - Online games and gamification

\begin{tabular}{ll}
\hline Online games and gamification & \multicolumn{1}{c}{ Website } \\
\hline Accounting Play & $\mathrm{https://accountingplay.com//}$ \\
Zombie Accountant & $\mathrm{https}: /$ goingloudstudios.com/games/zombie-accountant/ \\
SMU Accounting Challenge & $\mathrm{https}: / /$ apps.apple.com/us/app/smu-accounting-challenge/id610988772 \\
Ledger Mania & $\mathrm{https://www.ledgermania.com/}$ \\
Bank On It & $\mathrm{https}: / /$ www.startheregoplaces.com/ \\
DEBORAH & $\mathrm{https://deborahahg.wixsite.com/deborah}$ \\
\hline
\end{tabular}

Note: Websites were last accessed on January 26, 2021.

Table 6 - Business simulations and cases

\begin{tabular}{|c|c|}
\hline Business simulations and cases & Website \\
\hline The Business Strategy Game & https://www.bsg-online.com/ \\
\hline Capstone Business Simulation & https://www.capsim.com/ \\
\hline GLO-BUS & https://www.glo-bus.com/ \\
\hline $\begin{array}{l}\text { LINKS Enterprise Management Simulation and Supply Chain } \\
\text { Management Simulation }\end{array}$ & http://www.links-simulations.com/ \\
\hline $\begin{array}{l}\text { Marketplace Business } \\
\text { Simulation }\end{array}$ & https://www.marketplace-simulation.com/pt/ \\
\hline MikesBikes Advanced & https://www.smartsims.com/business-simulation/mikes-bikes-advanced/ \\
\hline
\end{tabular}

Note: Adapted from Riley et al. (2013). Websites were last accessed on January 26, 2021. 


\section{IMPLICATIONS FOR INSTRUCTORS AND STUDENTS}

This section debates the COVID-19 implications for instructors and students, focusing on its challenges. The social distancing is one of the most important preventing measures adopted by governments worldwide to restrict the impact of COVID-19 on people's health and has modified the way we socially interact, commercialize, and transmit knowledge. Masks and hand sanitizers are now promptly available everywhere we go, and virtual meetings and home office have become the rule.

\subsection{Instructors}

I want to emphasize three main implications for accounting instructors. The first regards the mode delivery. Due to social distancing, face-to-face format was shifted to remote learning and it required from instructors a new set of skill to manage VLEs and other tech resources. Although accounting educators are highly committed professionals to their students, Professor Samar El Sayad (as cited in Sangster et al., 2020) indicates that many students have experienced poor online education due to the lack of time of instructors to prepare high-quality educational resources. In face-to-face classes, it is common for students to use physical textbooks and materials. However, in remote learning, both instructors and students needed to go digital and this transition might not have been the best for many.

At this point in time, I think instructors are more skilled at using VLEs and VCTs than ever before and learning has been facilitated. The AAA continues to offer online training through webinars for accounting professors, which is really helpful for those who still have doubt or want to master tech tools. Also, older faculty might have felt more challenged when using these types of resources because of their little contact with them throughout their careers. Some might still struggle with setting their microphones, camera, and files. Nonetheless, I applaud those who, despite being before this challenging scenario, want to improve themselves and keep providing high-quality classes. That is the spirit!

The second implication concerns the instructors' mental and physical health, not only because of COVID-19 but also the modifications in the way they were used to teach. Significant changes in people's routines oftentimes are accompanied by anxiety, stress, or another type of preoccupation. Staying at home also means that people are not allowed to go to parks and other environments where they can exercise their bodies. Technology is pretty much the main recourse we have to stay distantly connected with one another without taking high risks of getting COVID-19.

Research has shown that mental diseases have increased since the pandemic started (Barzilay et al., 2020; Xiong et al., 2020). According to Xiong et al.'s (2020) systematic literature review, people from China, Spain, Italy, Iran, the US, Turkey, Nepal, and Denmark have reported high rates of anxiety, depression, post-traumatic stress disorder, psychological distress, and stress in general. In Brazil, where socioeconomic status is even more discrepant (Wanderley and Horton as cite in Sangster et al., 2020), there is no reason to believe otherwise. Brazilians are also mental loaded because of the effects of COVID-19 on their lives and the cases are still going up. Huge efforts have been made to provide vaccines for the general population as fast as it is possible. Still, we have a long way to go.

The final implication for instructors is unemployment. COVID-19 has affected many economic sectors, leaving workers without jobs. This also applies to accounting professors. Many have lost 
their jobs because education institutions could not afford their salaries as quarantine and other severe measures were adopted. Some might still be unemployed by today. Even though the government at its different levels has tried to help people in this regard, bills have continued to arrive at their doors. My hope is that vaccines can help accounting professors to get their jobs back and also that accounting education gets back to where it was left by these professionals.

Despite the unrecoverable harm the COVID-19 has been bringing to us, it made us stronger as a global community and more creative to deal with this situation. It has accelerated the process of digitalization (Reyneke et al., 2021) and people had more time to reflect on their lives. It showed that we can be truly resilient even at the hardest moments. The professor profession is one of the most precious jobs one can assume and sometimes it is undervalued. We should recognize it and be thankful for our instructors for their incredible commitment.

\subsection{Students}

Students have suffered from the similar consequences of COVID-19 (after all, we are all human beings). The transition from face-to-face education to remote learning might have been slightly easier for them, though. New generations of students who are entering the higher education world are used to and actually cannot live without technology tools. They are familiar with VLEs and VCTs and little or no training was needed. Controversially, some students might not even have appropriate remote devices to keep studying from their homes because there is inequality in socioeconomic statuses, especially in developing countries such as Brazil. Besides adaptation, another keyword is accessibility. Making devices affordable for students demanded time and financial resources. Some education institutions promoted campaigns to which people could donate money or devices. I can only hope students could get them by now.

The negative impacts that the COVID-19 pandemic is having on college students' mental health are another cause for concern worldwide. According to Son, Hegde, Smith, Wang, and Sasangohar's (2020) study, students declared that it had increased their levels of anxiety, stress, and depression. They also reported difficulty concentrating and sleeping, as well as concerns with their academic performance. Students have been recurring to others' support to cope with anxiety and stress. Psychological treatment is also an alternative and pills are applicable under medical supervision. In these hard times, students must care about their health at the same time they need to study and oftentimes work as well. It puts a heavier psychological load on them. They should not then be ashamed of asking for any kind of help.

Finally, it is not unusual for university students to depend on their parents or governmental policies to get income. As key organizations of the society, higher education institutions can also help students through scholarships and social projects. COVID-19 will continue to be an issue in the next years. In order to keep developing quality accountants, current students need to be able to focus on their academic life and then on their subsequent professional careers. Students are full of desires and willing to face challenges, but without appropriate support during an atypical period like this, it could be frustrating. As head of departments and instructors, we need to provide students support, motivation, and understandability. 


\section{NETNOGRAPHY STUDY}

This section reports a netnography study conducted at the beginning of the COVID-19 pandemic in Brazil. I first provide its general information and then I add the description of the data collection process as well as the results along with my experience.

\subsection{General characteristics}

Netnography is considered a research strategy and consists of conducting an ethnography study with online (internet) cultures or communities (Kozinets, 2002, 2010). "Netnography adapts common participant - observation ethnographic procedures - such as making cultural entrée, gathering data carefully analysing and interpreting those data, writing a research report and conducting ethical research - to the contingencies of online community manifesting through computer-mediated communications" (Kozinets, 2010, p. 18). Comparatively to the traditional ethnography method, nethnography is simpler, faster, and less expensive as a research and data collection approach (Kozinets, 2002, 2010). However, it does not mean it lacks rigor just because it is developed online.

Consistent with the objective of providing a more in-depth discussion of the implications of the COVID-19 for students, I have tracked the Facebook "Bolsistas Capes" group over the February 26-April 30, 2020. This private ${ }^{1}$ group had more than 67,000 members (as of May $6^{\text {th }}, 2020$ ) and this period reflects its initial reactions concerning the pandemic. The group was created on November 30 , 2011. I was its member since March 2017 and, therefore, I lived the good and bad news related to graduate education in Brazil like the other members. I felt I was inserted in this online community, which objective is to keep its members informed about the scholarships provided by Capes, as well as other issues of the graduate student's life.

The members of this online community can create a post on some topic, even if it is not directly related to graduate programs and students. In my experience with this community, I have never seen the amount of content that is posted per day in any other Facebook group that I participated in. There is too much raw data to be collected and analyzed. It became quite a challenge to map all the posting messages and their types. Although I have been tracking this community with more attention since February 26, 2020, I will report the data available on April 30, 2020 at the webpage of this group.

\subsection{Data collection and analysis}

There are many topics from multiple and distinct natures that were discussed from February 26 to April 30, 2020. I have collected the posts on May 11, 2020, and organized them into categories to better understand the posting messages. I chose the last day of April because it had a higher number of posts compared to prior days and then I would obtain a greater understandability towards this community. Table 7 describes the post categories and its frequencies.

In one day (April 30, 2020), a total of 103 posts were created by Bolsistas Capes members. These posts were structured into 12 categories (first column of Table 1). As expected, the "graduate education" category was the most frequent (24 posts, $23.3 \%$ ). This category involves posts that were directly related to graduate programs and students, such as formatting academic papers, translating work, journal suggestions, questions regarding tools to collect and analyze data, the announcement

1 For confidentiality purposes, none of the members of the "Bolsista Capes" group will be named, as well as the data collected will be disclosed in an aggregated form. 
of qualification and defense processes, and so forth. Many of these topics continue to be related to COVID-19 because it has been affecting graduate students and programs in unexpected ways. Graduate schools are having to adjust their rules and make concessions due to the consequences of this pandemic.

The "education \& government" category was the second most frequent, with 23 posts (22.3\%). The members of the Bolsista Capes community often discuss aspects related to their scholarship and its regulation. Also, they raise questions concerning graduate programs of other members and how they can help each other to make decisions. Even though each graduate program has its own rules that make them less comparable to each other, there is also common ground that graduate students exchange ideas as experiences. It can be related to due dates and deadlines for depositing the dissertation, as well as the modifications to the norms of scholarships, especially because of COVID-19.

A significant part of the number of the posts in the "memes \& sarcasm" category has to do with politicians or the Politics field. Together with "politics \& government" posts, they reached 22 posts (21.4\%). In COVID-19 times, much is demanded from the federal government. Every decision the Brazilian president takes toward research funding and graduate programs can influence the humor of the Bolsista Capes members. For this reason, the president is often the target of many memetype posts. Other politicians also receive significant attention and sarcasm from the community. Finally, I noted there are other categories with much less debate, but some of them were too related to COVID-19. For instance, the two posts of research questionnaires were related to the students' physical and mental health in the social distancing period.

Table 7 - Post type, description, and frequencies (April 30, 2020)

\begin{tabular}{|c|c|c|c|}
\hline Post type & Description & Frequency & $\%$ \\
\hline Deleted & Deleted messages (“This content ins't available right now”). & 2 & 1.9 \\
\hline Education & Posts that involve only the education field (like offering courses). & 8 & 7.8 \\
\hline $\begin{array}{l}\text { Education \& } \\
\text { government }\end{array}$ & $\begin{array}{l}\text { Posts that involve both Education and Government aspects (such as changes in } \\
\text { norms that regulate graduate students' scholarship). }\end{array}$ & 23 & 22.3 \\
\hline Education \& health & $\begin{array}{l}\text { Posts that involve both Education and Health aspects (such as reports that show } \\
\text { how universities are combatting COVID-19). }\end{array}$ & 2 & 1.9 \\
\hline Graduate education & $\begin{array}{l}\text { Posts related to graduate education aspects (such as formatting and translating } \\
\text { work, an indication of journals, plagiarism questions. etc.) }\end{array}$ & 24 & 23.3 \\
\hline Health & Posts related to both graduate students' and society's health. & 3 & 2.9 \\
\hline Health \& politics & $\begin{array}{l}\text { Posts that involve both Health and Politics aspects (such as the COVID-19 graphic } \\
\text { and the comments by the Brazilian president Jair Bolsonaro). }\end{array}$ & 2 & 1.9 \\
\hline Meme \& sarcasm & $\begin{array}{l}\text { Posts that. at some level. involves sarcasm through the use of memes. Most of them } \\
\text { are related to politicians. }\end{array}$ & 14 & 13.6 \\
\hline Other & Posts that do not fit in the created categories. & 13 & 12.7 \\
\hline $\begin{array}{l}\text { Politics \& } \\
\text { government }\end{array}$ & $\begin{array}{l}\text { Posts that involve both Politics and Government aspects (such as those that discuss } \\
\text { polemic media reports involving politicians and regulation. not necessarily related } \\
\text { to graduate programs or students). }\end{array}$ & 8 & 7.8 \\
\hline $\begin{array}{l}\text { Politics \& } \\
\text { indignation }\end{array}$ & Aggressive posts on politicians and/or Politics. & 2 & 1.9 \\
\hline $\begin{array}{l}\text { Research } \\
\text { questionnaire }\end{array}$ & Posts that ask graduate students to participate in studies. & 2 & 1.9 \\
\hline Total & Total number of posts & 103 & 100.0 \\
\hline
\end{tabular}


Next, Table 8 presents the number of reactions and comments per post type. A total of 5,734 reactions and 731 comments were made by the members on April 30, 2020. The "meme \& sarcasm" category received 3,491 comments $(60.9 \%)$. This result suggests that this category is more polemic and, therefore, receive more attention from the members of the community.

"Education \& government," "Politics \& government," and "Graduate education" posts also received considerable attention based on their numbers of reactions and comments. The members are more interested in what influences their academic life and Politics is a field where decisions are made. Then, it is natural for these categories to be the most interesting for graduate students. On the other hand, the two posts of "Politics \& indignation" category did not receive any reaction or comment.

Table 8 - Number of reactions and number of comments per post type (April 30, 2020)

\begin{tabular}{lcccc}
\hline Post type & \# of reactions & \% & \# of comments & \% \\
\hline Deleted & 1 & 0.0 & 1 & 0.1 \\
Education & 63 & 1.1 & 0 & 0.0 \\
Education \& government & 695 & 12.1 & 137 & 18.7 \\
Education \& health & 6 & 0.1 & 0 & 0.0 \\
Graduate education & 492 & 8.6 & 168 & 23.0 \\
Health & 104 & 1.8 & 138 & 1.0 \\
Health \& politics & 314 & 5.5 & 208 & 18.9 \\
Meme \& sarcasm & 3,491 & 60.9 & 42 & 28.5 \\
Other & 65 & 1.1 & 30 & 5.7 \\
Politics \& government & 502 & 8.8 & 0 & 4.1 \\
Politics \& indignation & 0 & 0.0 & 0 & 0.0 \\
Research questionnaire & 1 & 0.0 & 731 & 0.0 \\
Total & 5,734 & 100.0 & & \\
\hline
\end{tabular}

Finally, Table 9 reports the representativeness of COVID-19-related posts. A total of 38 (out of 103) posts were directly related to COVID-19 and almost all categories possessed at least one post. The posts from the category "Deleted" were excluded in this part of the analysis because they did not allow me to know whether they were related or not to COVID-19.

Table 9 - Representativeness of COVID-19-related posts per post type (April 30, 2020)

\begin{tabular}{lccc}
\hline Post type & \# of COVID-19-related posts & \% & Total \# of posts \\
\hline Education & 3 & $37.5 \%$ & 8 \\
Education \& government & 15 & $65.2 \%$ & 23 \\
Education \& health & 2 & $100.0 \%$ & 2 \\
Graduate education & 1 & $4.2 \%$ & 24 \\
Health & 3 & $100.0 \%$ & 3 \\
Health \& politics & 2 & $100.0 \%$ & 2 \\
Meme \& sarcasm & 6 & $42.9 \%$ & 14 \\
Other & 3 & $23.0 \%$ & 13 \\
Politics \& government & 2 & $25.0 \%$ & 8 \\
Politics \& indignation & 0 & $0.0 \%$ & 2 \\
Research questionnaire & 1 & $50.0 \%$ & 2 \\
Total & 38 & $37.6 \%$ & 101 \\
\hline
\end{tabular}


I observe that $37.6 \%$ (38 out of 101) of the total number of posts were related to COVID-19. More than one-third of the posts on April 30, 2020, posted on the Bolsista Capes' webpage, were about COVID-19 and involved a series of topics and knowledge fields. Due to the low number of posts, some categories reached $100.0 \%$ of representativeness of COVID-19-related posts (i.e., "Education \& health," "Education \& indignation," "Health," and "Health and politics"). These are associated with health aspects and, thus, are expected to be connected to the novel coronavirus. For "education $\&$ government" posts, $65.2 \%$ were directly related to the pandemic. It suggests that the overlap between the Education and Politics fields is a key domain for graduate students and their academic lives. Significant norm changes were made to accommodate the new reality and while some of them were positive, others were questioned. The Bolsista Capes members strongly criticized many of the decisions of the Brazilian president at that time, including the lack of money to maintain the number of scholarships active and the reduction of the governmental budget spent on research activities.

On the other hand, $62.4 \%$ were not COVID-19-related posts. I highlight the representativeness of the "graduate education" category (4.2\%). Only one post regards COVID-19. It suggests that graduate students' issues not necessarily involve the novel coronavirus and its implications. It is essential to consider that some categories have a low number of posts. Consequently, the relative frequency is more sensitive. These results should then be observed cautiously. Despite that, they provide an outlook about how much debate exists in an online academic community in only one day of analysis. Because the Bolsista Capes group has more than 67,000 members, there are too many posts to track every day. Hand-collecting these 103 posts were difficult and took a significant part of my time.

In addition to the data from the Bolsista Capes group, I report some of my key experiences with the COVID-19 pandemic. Being a doctoral student is not easy. There is work to do and most importantly it must be done whenever it requires to be done. I have worked during weekdays and weekends. This flexibility is both positive and negative. I am in this academic path for almost six years now and feel anxious when I have work to do, even if it is a Sunday. This pandemic made it more difficult. Though, I am fortunate to have an advisor who understands what it takes to be a doctoral student and alleviate my concerns.

A positive experience during these hard times is the proximity with my family. I am closer to my parents than I ever was since I decided to follow an academic path. My family has been providing me with absolute support and I am grateful for having the condition I have. I get to talk to my parents and "little" sister daily and am able to be less concerned with my routine. I restarted to exercise my body regularly and started attending psychological and psychiatry sessions for the first time in my life. I have been working on research projects with talented colleagues and attended online conferences, many of which would hardly be possible if they were not virtual. And, although this pandemic has brought irreversible losses, I am trying to stay positive.

\section{CLOSING THOUGHTS}

The purpose of this work was to promote reflections upon remote learning in accounting education in Brazil during the social distancing period due to the COVID-19 pandemic. Additionally, a study based on the netnography approach was developed to deepen the debate on how COVID-19 has been affecting graduate students. I also reported some personal experiences lived at the beginning of the pandemic.

Many accounting instructors had to move from onsite education to remote learning out of the blue, without proper skills and training. For this reason, I intended to bring the role of technology tools and I hope they will be useful for accounting educators somehow. Regarding the implications for instructors and students, my objective was to recognize the efforts these publics are doing to keep 
education alive during the hard times we are living. Instructors and students had considerable changes in their daily routines. They have to take care of themselves without forgetting their commitment to their education life. I hope I have raised some insightful points.

For my netnography study, I was part of an online community of graduate students and could observe its initial reaction to the COVID-19. More than one third of the posts were directly associated to the pandemic, which is an indication that this theme has been a concerning topic among them. In my experience, my colleagues have been supporting me in my academic and personal lives. I discuss my problems and share some of my victories (mostly papers accepted for publication) with them. I am also incredibly grateful for having such a supportive family in which I can deposit my trust without hesitation, in COVID-19 times or otherwise.

Finally, despite the unfortunate scenario brought by the COVID-19, I could see commitment and solidarity by and among human beings to develop vaccines. I also could note the importance of the professions in combatting it and cooperating to find ways to deaccelerate its spreading. The accounting field and its professionals are relevant agents to continue to serve society with their financial services. In particular, accountants can be of assistance to the owners of small enterprises when it comes to cash flow management and help save them from bankruptcy. This is an opportunity to show the value of the accounting profession, as well as its commitment to society and the public interest.

Hopefully, the reflections of this work will reach those who need help with technologyinstructional materials and who are interested in what is going on with an online academic community. Based on my experiences, I sympathize with those who need physical or psychological help because there are pretty tough times, but I hope that we can overcome it together.

\section{REFERENCES}

Barzilay, R., Moore, T. M., Greenberg, D. M., DiDomenico, G. E., Brown, L. A., White, L. K., ... Gur, R. E. (2020). Resilience, COVID-19-related stress, anxiety and depression during the pandemic in a large population enriched for healthcare providers. Translational Psychiatry, 10(1), 291. https://doi.org/10.1038/ s41398-020-00982-4

Bell, K. (2018). Game on! Gamification, gameful design, and the rise of the gamer educator. Baltimore: John Hopkins University Press.

Buckley, P., \& Doyle, E. (2016). Gamification and student motivation. Interactive Learning Environments, 24(6), 1162-1175. https://doi.org/10.1080/10494820.2014.964263

Calabor, M. S., Mora, A., \& Moya, S. (2019). The future of "serious games" in accounting education: A Delphi study. Journal of Accounting Education, 46(April 2017), 43-52. https://doi.org/10.1016/j. jaccedu.2018.12.004

Carenys, J., \& Moya, S. (2016). Digital game-based learning in accounting and business education. Accounting Education, 25(6), 598-651. https://doi.org/10.1080/09639284.2016.1241951

Charron, K., \& Raschke, R. (2014). Student Perceptions and Experiences Using Jing and Skype in an Accounting Information Systems Class. Journal of Education for Business, 89(1), 1-6. https://doi.org/10. $1080 / 08832323.2012 .733740$

D’Aquila, J. M., Wang, D., \& Mattia, A. (2019). Are instructor generated YouTube videos effective in accounting classes? A study of student performance, engagement, motivation, and perception. Journal of Accounting Education, 47, 63-74. https://doi.org/10.1016/j.jaccedu.2019.02.002 
Fogarty, T. J. (2020). Accounting education in the post-COVID world: looking into the Mirror of Erised. Accounting Education, 29(6), 563-571. https://doi.org/10.1080/09639284.2020.1852945

Fortin, A., Viger, C., Deslandes, M., Callimaci, A., \& Desforges, P. (2019). Accounting students' choice of blended learning format and its impact on performance and satisfaction. Accounting Education, 28(4), 353-383. https://doi.org/10.1080/09639284.2019.1586553

Hoelscher, J., \& Mortimer, A. (2018). Using Tableau to visualize data and drive decision-making. Journal of Accounting Education, 44(October 2017), 49-59. https://doi.org/10.1016/j.jaccedu.2018.05.002

Holtzblatt, M., \& Tschakert, N. (2011). Expanding your accounting classroom with digital video technology. Journal of Accounting Education, 29(2-3), 100-121. https://doi.org/10.1016/j.jaccedu.2011.10.003

Istenic Starčič, A., Cotic, M., Solomonides, I., \& Volk, M. (2016). Engaging preservice primary and preprimary school teachers in digital storytelling for the teaching and learning of mathematics. British Journal of Educational Technology, 47(1), 29-50. https://doi.org/10.1111/bjet.12253

Kokina, J., \& Juras, P. E. (2017). Using Socrative to enhance instruction in an accounting classroom. Journal of Emerging Technologies in Accounting, 14(1), 85-97. https://doi.org/10.2308/jeta-51700

Kozinets, R. V. (2002). The Field Behind The Screen: Using Netnography Marketing Communities. Journal of Marketing, 39(1), 61-72. Retrieved from http://www.jstor.org/stable/1558584

Kozinets, R. V. (2010). Netnography: Doing ethnographic research online. London: Sage.

Paz, V. (2017). Innovative New Apps and Uses for the Accounting Classroom. Journal of Emerging Technologies in Accounting, 14(1), 63-75. https://doi.org/10.2308/jeta-51653

Premuroso, R. F., Tong, L., \& Beed, T. K. (2011). Does using clickers in the classroom matter to student performance and satisfaction when taking the introductory financial accounting course? Issues in Accounting Education, 26(4), 701-723. https://doi.org/10.2308/iace-50066

Reyneke, Y., Shuttleworth, C. C., \& Visagie, R. G. (2021). Pivot to online in a post-COVID-19 world: critically applying BSCS 5E to enhance plagiarism awareness of accounting students. Accounting Education, 1-21. https://doi.org/10.1080/09639284.2020.1867875

Riley, R. A. (Dick), Cadotte, E. R., Bonney, L., \& MacGuire, C. (2013). Using a Business Simulation to Enhance Accounting Education. Issues in Accounting Education, 28(4), 801-822. https://doi.org/10.2308/ iace-50512

Rizun, M., \& Strzelecki, A. (2020). Students' Acceptance of the COVID-19 Impact on Shifting Higher Education to Distance Learning in Poland. International Journal of Environmental Research and Public Health, 17(18), 6468. https://doi.org/10.3390/ijerph17186468

Sangster, A., Stoner, G., \& Flood, B. (2020). Insights into accounting education in a COVID-19 world. Accounting Education, 29(5), 431-562. https://doi.org/10.1080/09639284.2020.1808487

Son, C., Hegde, S., Smith, A., Wang, X., \& Sasangohar, F. (2020). Effects of COVID-19 on College Students' Mental Health in the United States: Interview Survey Study. Journal of Medical Internet Research, 22(9), e21279. https://doi.org/10.2196/21279

Taylor, M., Marrone, M., Tayar, M., \& Mueller, B. (2017). Digital storytelling and visual metaphor in lectures: a study of student engagement. Accounting Education, 0(0), 1-18. https://doi.org/10.1080/09639284.2017 .1361848

Watty, K., McKay, J., \& Ngo, L. (2016). Innovators or inhibitors? Accounting faculty resistance to new educational technologies in higher education. Journal of Accounting Education, 36, 1-15. https://doi. org/10.1016/j.jaccedu.2016.03.003

Xiong, J., Lipsitz, O., Nasri, F., Lui, L. M. W., Gill, H., Phan, L., ... McIntyre, R. S. (2020). Impact of COVID-19 pandemic on mental health in the general population: A systematic review. Journal of Affective Disorders, 277(August), 55-64. https://doi.org/10.1016/j.jad.2020.08.001 